\title{
ANALISIS PENGARUH MANAJEMEN RISIKO TERHADAP KINERJA KEUANGAN PERBANKAN YANG TERDAFTAR DI BEI
}

\author{
Bhirgita Christine Dwi Yanti ${ }^{1 *}$, Adi Irawan Setiyanto ${ }^{2)}$ \\ ${ }^{1}$ Manajemn Bisnis, Politeknik Negeri Batam \\ email: bhirgitacrs@gmail.com \\ ${ }^{2}$ Manajemen Bisnis, Politeknik Negeri Batam \\ email: adiirawan@polibatam.ac.id
}

\begin{abstract}
Banks have a strategic role in national economic development. The large number of funds managed by banks causes the risks faced are also very large. Very supportive if the risk affects the bank's performance, therefore banks are required to implement risk management. After being selected using the purposive sampling method, the sample banks were 21 banks. Tests carried out with multiple regression analysis show that bad loans and operating expenses on operating income negatively affect asset returns. In contrast to the loan to deposit ratio which does not affect the return on assets. Based on the results of this study, it is necessary to optimize credit and operational risks which are considered capable of maintaining the stability of bank profitability.
\end{abstract}

Keyword: Risk Management, Financial Performance

Bank memiliki peran strategis dalam pembangunan ekonomi nasional. Banyaknya dana yang dikelola oleh bank menyebabkan risiko yang dihadapi juga sangat besar. Sangat memungkinkan jika risiko tersebut memengaruhi kinerja keuangan bank, oleh sebab itu bank diharuskan menerapkan manajemen risiko. Setelah dipilih menggunakan metode purposive sampling, bank yang menjadi sampel berjumlah 21 bank. Pengujian dilakukan dengan analisis regres berganda menunjukkan bahwa non-performing loan dan beban operasional terhadap pendapatan operasional secara negatif signifikan mempengaruhi return on asset. Berbeda dengan loan to deposit ratio yang tidak mempengaruhi return on asset. Berdasarkan hasil penelitian ini, perlunya pengoptimalan dari risiko kredit dan operasional yang dianggap mampu menjaga kestabilan profitabilitas bank.

Kata Kunci: Manajemen Risiko, Kinerja Keuangan

*E-mail: bhirgitacrs@gmail.com 


\section{PENDAHULAN}

Berbicara tentang kesejahteraan suatu negara berarti mencakup segala aspek yang ada dalam negara tersebut, termasuk kesejahteraan rakyatnya. Suatu negara dalam pembangunan ekonominya membutuhkan modal atau dana yang tidak sedikit. Sebagaimana tertuang dalam pembukaan UUD 1945, pembangun ekonomi dilakukan sebagai upaya untuk memajukan kesejahteraan umum.

Dalam pembangunan ekonomi nasional, lembaga keuangan bank memiliki peran yang strategis dalam memberikan jasa keuangan, mengumpulkan dan mendistribusikan dana secara langsung kepada masyarakat. Salah satu kontribusi besar yang dilakukan bank dalam perkembangan dan pertumbuhan ekonomi nasional ialah, pemberian kredit kepada UMKM ataupun usaha lainnya (Simatupang, 2019). Bank dianggap mampu mengatur dan mengelola transaksi keuangan secara cepat apabila dibandingkan dengan lembaga keuangan lainnya.

Berbagai kalangan semakin melirik dunia perbankan yang membuat bank mau tidak mau harus terus mengoptimalkan kinerjanya. Rasio keuangan dapat dijadikan sebagai pengukur kinerja suatu bank. Hal tersebut juga disebutkan dalam Surat Edaran Bank Indonesia Nomor 13/30/DPNP Tanggal 16 Desember 2011, dimana terdapat rasio seperti ROA (Return on Asset) dan ROE (Return on Equity) dapat digunakan sebagai pengukur financial performance. Pengukuran tingkat pengambalian asset bank menggunakan ROA sedangkan untuk mengukur kemampuannya dalam memperoleh laba dari modal yang tersedia, bank menggunakan ROE. Bank dianggap memiliki kinerja yang baik, apabila rasio profitabilitasnya terus mengalami peningkatan. Demi menjaga agar profitabilitas terus meningkat, bank diharapkan mampu dalam mengidentifikasi risiko serta menganalisisnya untuk mengurangi kemungkinan yang dapat merugikan.

Sektor perbankan di Indonesia menyadari bahwa setiap risiko yang disebutkan dalam Surat Edaran Otoritas Jasa Keuangan No.14/SEOJK.03/2017 dapat mempengaruhi financial position serta kinerjanya. Dana yang diatur dan dikelola bank jumlahnya tidak sedikit, sehingga risiko yang dihadapi pun sangat besar. Oleh karena itu, penerapan manajemen risiko dinilai wajib dikarenakan dapat mendeteksi risiko yang memungkinkan perusahaan mengalami kerugian. Menurut Peraturan Bank Indonesia 5/8/PBI/2003, pengelolaan risiko dilakukan melalui beberapa tahapan, seperti pengidentifikasian, pengukuran, monitoring, dan pengendalian. Dikarenakan sering kali penerapan manajemen risiko disalahartikan, bahkan dianggap memberi pengaruh negatif serta penghambat dalam kemajuan bank. Setelah menghadapi krisis moneter bahkan krisis keuangan global, pelaku ekonomi baru menyadari betapa pentingnya penerapan manajemen risiko dalam dunia perbankan atau lembaga keuangan lainnya bahkan penerapan manajemen risiko dianggap sebagai kebutuhan (Mardiana, 2018).

Penelitian sebelumnya tentang hal yang sama menunjukkan hasil yang bermacam-macam, seperti penelitian Mardiana (2018) yang menyatakan adanya pengaruh positif signifikan antara manajemen risiko (CAR, BOPO dan NPL) secara bersamaan terhadap kinerja keuangan bank. Secara parsial, terdapat pengaruh signifikan antara BOPO terhadap kinerja keuangan bank. Berbeda dengan CAR dan NPL yang tidak memiliki pengaruh. Dalam 
penelitiannya, Badawi (2017) juga menyatakan terdapat pengaruh antara NPL, LDR dan NIM terhadap ROE.

Penelitian Ismanto (2020) menyebutkan risiko likuiditas, kredit serta operasional dan suku bunga memiliki pengaruh signifikan terhadap financial performance. Berbeda dengan parsial, yang memiliki pengaruh paling signifikan adalah risiko kredit, operasional dan suku bunga. Penelitian lain dari Attar, Islahuddin, \& M. Shabri (2014) menyatakan bahwa secara simultan adanya pengaruh antara NPL, BOPO dan LDR terhadap kinerja keuangan bank. Sedangkan secara parsial, hanya NPL dan BOPO yang memiliki pengaruh terhadap kinerja keuangan.

Manajemen risiko merupakan hal yang wajib diterapkan oleh industri keuangan perbankan guna mengidentifikasi risiko yang kemungkinan terjadi demi meningkatkan kinerja dan profitabilitas perbankan. Penelitian ini dilakukan dengan menggunakan data pada lembaga keuangan bank pada periode 2015-2019. Letak perbedaan penelitian ini dengan penelitian sebelumnya terdapat divariabel independennya, dimana penambahan variabel loan to deposit ratio dan beban operasional terhadap pendapatan operasional sebagai proksi dari risiko likuiditas dan operasional.

\section{KAJIAN LITERATUR}

\section{Signalling Theory (Teori Sinyal)}

Signalling theory menyatakan bagaimana manajemen menunjukkan potensi yang dimiliki perusahaan kepada investor (Brigham \& Houston, 2011). Sinyal yang dikeluarkan dapat berupa laporan keuangan yang digunakan pihak eksternal untuk mengetahui kualitas sebuah perusahaan dan bagaimana potensinya di masa yang akan datang, yang bisa mempengaruhi keputusan investor untuk berinvestasi.

\section{Risiko dan Manajemen Risiko}

Risiko merupakan suatu situasi yang tidak pasti, dimana keadaan yang terjadi di masa depan (future) diputuskan berdasarkan pertimbangan saat ini sedangkan manajemen risiko menjelaskan bagaimana organisasi dapat mengatasi segala masalah yang ada menggunakan berbagai pendekatan manajemen secara menyeluruh dan sistematis (Fahmi, 2016).

\section{Kinerja Keuangan dan Rasio Keuangan}

Kinerja Keuangan ialah analisis yang menjelaskan bagaimana perusahaan menerapkan dengan benar setiap aturan pelaksanaan keuangan (Fahmi, 2012). Sedangkan rasio keuangan merupakan tolak ukur yang digunakan dalam menilai kondisi keuangan perusahaan, dengan membandingkan nilai yang terdapat pada laporan keuangan (Sawir, 2001). Investor akan melihat rasio yang paling sesuai dengan analisisnya, jika rasio tersebut tidak sesuai dengan tujuan analisisnya, ia tidak akan menggunakannya.

TASSEW \& HAILU (2019) melakukan penelitian terhadap 17 commercial bank di Ethiopia pada periode 2013 hingga 2017, berdasarkan penelitian yang telah dilakukan didaptkan hasil yang menunjukkan risiko kredit, likuiditas serta operasional dan pasar memberikan pengaruh negatif signifikan terhadap kinerja keuangan.

Attar, Islahuddin, \& M. Shabri (2014) melakukan penelitian terhadap perbankan yang listing di BEI periode 2007 hingga 2011. Berdasarkan hasil pengujian secara bersamaan (simultan) didapati bahwa manajamen risiko (kredit, likuiditas, dan operasional) memengaruhi kinerja keuangan bank. Berbeda dengan uji parsial, yang paling 
memengaruhi kinerja keuangan ialah risiko kredit dan operasional.

Kansil, Murni, \& Tulung (2017) melakukan penelitian pada Bank Pembangunan Daerah se-Indonesia periode 2013-2015. Mereka mendapati bahwa secara bersamaan NPL, NIM, LDR, dan BOPO memengaruhi ROA. Uji parsial membuktikan yang memberikan pengaruh negatif signifikan terhadap ROA ialah NPL dan BOPO, berbeda dengan NIM yang memberikan dampak positif signifikan terhadap ROA.

Pratiwi (2017) menyebutkan bahwa secara simultan, penerapan manajemen risiko berdampak pada kinerja perusahaan. Ketika dijelaskan lebih rinci, penelitian ini memberikan hasil bahwa rasio NIM dan CAR memberikan dampak terhadap ROE sedangkan NPL dan LDR belum memberikan pengaruh yang cukup. Penelitian Mansyur (2017) menunjukkan bahwa NPL dan NIM memberikan dampak pada financial performance sedangkan LDR dan $\mathrm{Net}$ Open Position Ratio tidak memberikan dampak yang cukup pada financial performance.

Peneliti Eng (2013) menyebutkan dalam hasil penelitiannya, secara simultan NIM, BOPO, NPL, serta LDR dan CAR mempengaruhi ROA. Sedangkan secara parsial hanya NIM, LDR, dan NPL yang mempengaruhi ROA. Hasil lain penelitian ini juga menyebutkan bahwa variabel NIM yang memberikan pengaruh paling besar terhadap ROA.

\section{Hipotesis}

\section{Pengaruh Non-Performing Loan terhadap Return on Asset}

Sebagai salah satu indikator penilai kinerja bank, NPL menggambarkan kemampuan bank dalam mengatasi kredit bermasalahnya ke dalam bentuk rasio. Dimana apabila rasio NPL yang merepresentasikan kredit bermasalah semakin tinggi, dapat mengakibatkan pendapatan ataupun laba menurun sehingga bank tersebut dianggap tidak sehat dan dianggap gagal dalam mengelola kredit bermasalahnya (Dwihandayani, 2017). Penelitian (Attar, Islahuddin, \& M. Shabri, 2014) menyebutkan bahwa penerapan NPL berdampak negatif terhadap ROA dan ROE. Penelitian (Mansyur, 2017) yang juga menemukan pengaruh negatif yang signifikan NPL terhadap ROA. Dari sini dapat disimpulkan bahwa apabila nilai NPL bertambah akan mengakibtkan berkurangnya nilai ROA maupun ROE. Mengacu pada sedikit penjelasan di atas, maka akan diuji:

H1: Non-Performing Loan berpengaruh negatif terhadap Kinerja Keuangan.

\section{Pengaruh Loan to Deposit Ratio terhadap Return on Asset}

Dalam menilai tingkat likuiditas, bank menggunakan rasio ini untuk melihat kemampuannya dalam memenuhi loan request dengan menggunakan jumlah dana yang diterima. Nilai rasio LDR yang tinggi menandakan bank tidak likuid karena telah meminjamkan seluruh dananya. Penelitian (Sathyamoorthi C. R, Mapharing, Mphoeng , \& Dzimiri, 2020) dan penelitian (Badawi, 2017) menyatakan hal yang sama bahwa LDR berperan dan berpengaruh negatif signifikan terhadap kinerja keuangan. Yang berarti semakin tinggi nilai LDR akan menyebabkan kinerja keuangan bank menurun. Berdasarkan penjelasan tersebut, hipotesis yang hendak diuji adalah:

H2: Loan to Deposit Ratio berpengaruh negatif terhadap Kinerja Keuangan.

Pengaruh $\begin{gathered}\text { Beban } \\ \text { terhadap }\end{gathered}$ Opendapatan
terhadap Return on Asset


Sebagai indikator pengukur tingakat operasional, rasio BOPO menggambarkan tingkat efisiensi bank dalam pengoperasiannya. Jika pendapatan operasional tidak mampu menutupi beban operasional maka bank dianggap tidak sehat karena dianggap tidak mampu mengendalikan biaya operasionalnya. Dikarenakan hal tersebut dapat menyebabkan kerugian bagi bank. Penelitian Santosa (2019) dan Munawaroh \& Azwari (2019) memiliki hasil penelitian yang sama-sama menyatakan bahwa financial performance juga dipengaruhi secara negatif oleh BOPO. Yang berarti, meningkatnya nilai BOPO akan membuat kinerja keuangan bank menurun, dikarenakan pendapatan yang diperoleh dari operasional jumlahnya lebih kecil dibandingkan dengan biaya operasional. Sehingga akan diuji:

H3: Beban Operasional terhadap Pendapatan Operasional berpengaruh negatif terhadap Kinerja Keuangan.

\section{METODE PENELITIAN}

Penelitian dilakukan dengan pendekatan kuantitatif menggunakan data sekunder, dimana data tersebut bersumber dari website resmi Bursa Efek Indonesia. Lokasi pelaksanaan penelitian di Bursa Efek Indonesia dan laporan tahunan bank digunakan sebagai objek penelitian. Populasi dalam peneltian ini ialah seluruh lembaga keuangan bank yang terdaftar pada BEI tahun 20152019. Karena keterbatasan penulis, maka sampel ditetapkan dengan menggunakan menggunakan metode non-probabilitas, purposive sampling. Data yang digunakan dalam penelitian ini dikumpulkan melalui data arsip dari website resmi BEI www.idx.co.id.

\section{HASIL DAN PEMBAHASAN}

Table 1 Statistik Deskriptif

\begin{tabular}{|l|r|r|r|r|r}
\multicolumn{5}{c}{ Descriptive Statistics } & \\
& $\mathrm{N}$ & Minimum & Maximum & Mean & Std. Deviation \\
\hline NPL & 105 & .00180 & .08720 & .0256610 & .01522105 \\
\hline LDR & 105 & .55370 & 1.78090 & .9035819 & .15853700 \\
\hline BOPO & 105 & .35900 & .98880 & .7454371 & .12586055 \\
\hline ROA & 105 & .00110 & .03970 & .0188171 & .01008605 \\
\hline Valid N (listwise) & 105 & & & & \\
\hline
\end{tabular}

Sumber: Output SPSS, 2021

Mengacu pada hasil ringkasan statistik di atas, dari 105 data yang dimiliki NPL nilai minimum dan maksimum yakni sebesar 0,0018 dan 0,0872. Pada data NPL tidak terdapat kesenjangan data yang terlalu besar, hal tersebut dapat dilihat dari nilai standar deviasi yang lebih kecil dari rata-rata.

Ringkasan statistik di atas juga mengungkapkan nilai minimum dan maksimum yang dimiliki LDR, yaitu sebesar 0,5537 dan 1,7809. Sama halnya dengan NPL, LDR tidak memiliki kesenjangan data yang terlalu besar dikarenakan standar deviasi yang dimiliki nilainya lebih kecil dibandingkan dengan nilai mean-nya.

Ringkasan statistik variabel BOPO dengan 105 data yang digunakan menunjukkan nilai minimum terletak pada angka 0,3590 sedangkan maksimum sebesar 0,9888 . Sedangkan standar deviasi sebesar 0,125860 (kecil dari mean) menandakan bahwa kesenjangan data yang tidak terlalu besar.

Variabel ROA dalam ringkasan statistic di atas disebutkan mempunyai nilai minimum 0,0011 dan maksimum 0,0397. Standar deviasi 0,0100860 lebih kecil dari rata-rata 0,018817 menandakan tidak terdapat kesenjangan data yang terlalu besar. 
Table 2 Uji Normalitas

One-Sample Kolmogorov-Smirnov Test

\begin{tabular}{|c|c|c|}
\hline & & $\begin{array}{l}\text { Unstandardiz } \\
\text { ed Residual }\end{array}$ \\
\hline N & & 105 \\
\hline \multirow[t]{2}{*}{ Normal Parameters ${ }^{a, b}$} & Mean & .0000000 \\
\hline & Std. Deviation & .00729762 \\
\hline \multirow[t]{3}{*}{ Most Extreme Differences } & Absolute & .063 \\
\hline & Positive & .063 \\
\hline & Negative & -.045 \\
\hline \multicolumn{2}{|l|}{ Test Statistic } & .063 \\
\hline \multicolumn{2}{|l|}{ Asymp. Sig. (2-tailed) } & $200^{c, d}$ \\
\hline \multicolumn{3}{|c|}{ a. Test distribution is Normal. } \\
\hline \multicolumn{3}{|l|}{ b. Calculated from data. } \\
\hline \multicolumn{3}{|c|}{ c. Lilliefors Significance Correction. } \\
\hline \multicolumn{3}{|c|}{ d. This is a lower bound of the true significance. } \\
\hline
\end{tabular}

Sumber: Output SPSS, 2021

Berdasarkan hasil pengujian di atas dapat diketahui bahwa nilai Sig. yang diperoleh pada penelitian ini lebih besar dari 0,05. Hal tersebut menyimpulkan bahwa seluruh data yang digunakan dalam penelitian ini sudah berdistribusi normal.

Table 3 Uji Multikolinearitas

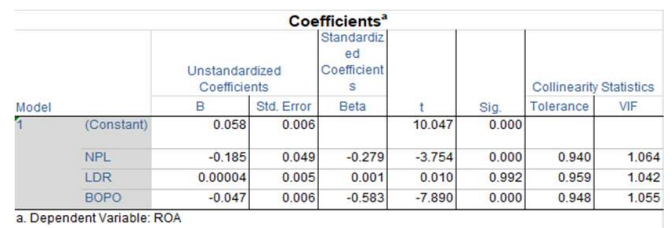

Sumber: Output SPSS, 2021

Hasil pengujian statistik di atas menunjukkan nilai tolerance dan VIF masing-masing variabel. NPL memiliki nilai tolerance dan VIF masing-masing 0,940 dan 1,064. LDR dengan nilai masing-masing sebesar 0,959 dan 1,042 sedangkan BOPO dengan nilai masingmasing sebesar 0,948 dan 1,055. Hal tersebut mengindikasikan bahwa model regresi pada penelitian ini terbebas dari problem multikolinearitas dikarenakan tidak ditemukannya korelasi antar variabel bebasnya.
Table 4 Uji Autokorelasi

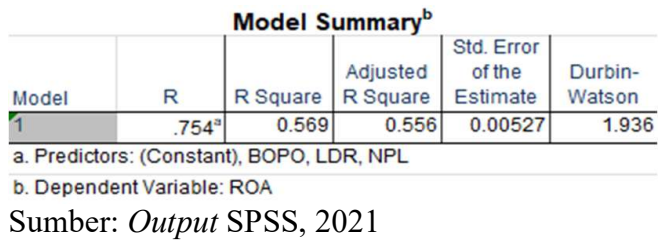

Mengacu pada hasil pengujian di atas, dapat diketahui bahwa nilai DW penelitian ini senilai 1,936. Selanjutnya akan dianalisis dan dibandingkan dengan nilai du yang terdapat pada DurbinWatson Statistic Table dengan nilai signifikansi 5\%, $n$ sebanyak 105 data dan jumlah variabel bebas $3(\mathrm{k}=3)$. Maka dari itu didapati nilai du sebesar 1,736. Dengan rumus DW $>\mathrm{du}<(4-\mathrm{du})$ atau $1,936>1,736<(4-1,736)$ maka dipastikan tidak terdapat gejala autokorelasi pada model regresi yang digunakan.

Table 5 Analisis Linear Berganda

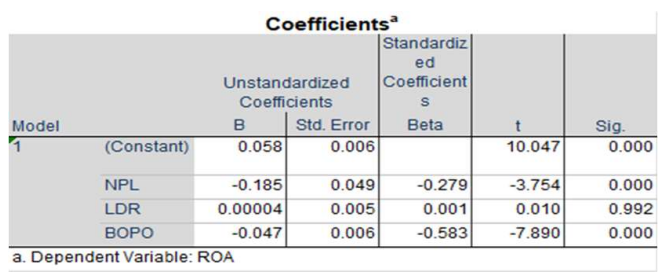

Sumber: Output SPSS, 2021

Hasil uji statistik di atas memperlihatkan nilai konstanta dan koefisien regresi yang digunakan untuk melengkapi persamaan regresi sebagai berikut:

\section{ROA $=0,058-0,185 N P L+$ 0,00004LDR - 0,047BOPO}

Adapun hasil model regrsi linear berganda di atas adalah sebagai berikut:

1) Nilai constant ataupun konstanta diperoleh dari hasil uji statistik pada tabel 4.6 yaitu sebesar 
0,058. Yang memiliki arti, jika variabel bebas NPL, LDR maupun BOPO sama dengan 0 maka variabel tetap yakni ROA akan bernilai 0,058 .

2) Dengan arah negatif, koefisien regresi dari variabel NPL sebesar -0,187 yang memiliki makna apabila NPL naik sebesar satu satuan akan mengakibatkan variabel ROA turun sebanyak 0,187 satuan. Begitupun sebaliknya. Dengan asumsi, variabel lain diluar NPL konstan atau tetap.

3) Berbeda dengan NPL, koefisien regresi variabel LDR memiliki nilai dengan arah positif sebesar 0,00004 yang berarti apabila LDR mengalami peningkatan satu satuan maka akan mengakibatkan nilai variabel ROA naik sebesar 0,00004 satuan. Dengan asumsi, variabel lain diluar variabel ini konstan atau tetap.

4) Variabel BOPO memiliki koefisien regresi dengan arah negatif sebesar $-0,047$ yang mengartikan akan terjadi penurunan pada ROA sebesar 0,047 apabila variabel BOPO mengalami peningkatan sejumlah satu satuan. Begitu pula sebaliknya. Dengan anggapan, variabel lain diluar BOPO konstan atau tetap.

Table 6 Koefisien Determinasi

\begin{tabular}{l|l|c|c|r}
\multicolumn{8}{c}{ Model Summary } \\
Model & R & R Square & $\begin{array}{c}\text { Adjusted R } \\
\text { Square }\end{array}$ & $\begin{array}{c}\text { Std. Error of } \\
\text { the Estimate }\end{array}$ \\
\hline 1 & $.690^{\mathrm{a}}$ & .476 & .461 & .00740521 \\
\hline \multicolumn{3}{l}{ a. Predictors: (Constant), BOPO, LDR, NPL }
\end{tabular}

Sumber: Output SPSS, 2021

Berdasarkan hasil yang tertera pada tabel di atas, diketahui $R$ Square bernilai sebesar 0,476 atau $47,6 \%$. Yang berarti pada model regresi yang digunakan variabel bebas NPL, LDR, dan BOPO memberikan pengaruh ataupun informasi terkait variabel tetap ROA sebanyak 47,6\%. Pengaruh lain sebanyak 52,4\% $(100 \%$ - 47,6\%) diberikan oleh variabel lain yang tidak terdapat dalam model regresi peneliatian ini.

Table 7 Uji F

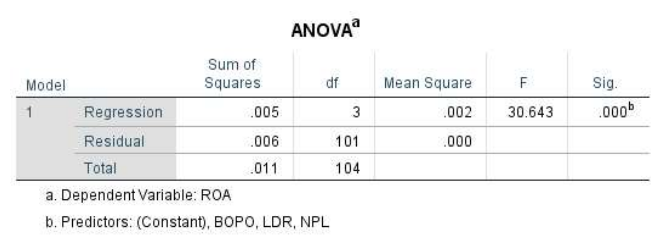

Sumber: Output SPSS, 2021

Mengacu pada hasil uji statistik di atas, nilai $f$ hitung yang diperoleh ialah sebesar 30,643 dan nilai Sig. sebesar 0,000 . Hal ini membuktikan bahwa secara simultan seluruh variabel bebas yang digunakan dalam penelitian ini memengaruhi variabel tetap, ROA. Dikarenakan nilai Sig. 0,000 kecil dari taraf signifikan yang digunakan yakni 0,05 .

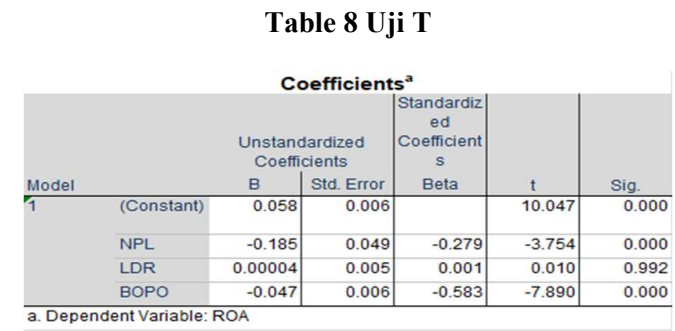

Sumber: Output SPSS, 2021

Hasil uji statistik $\mathrm{t}$ di atas menunjukkan nilai Sig. yang dimiliki variabel NPL yakni 0,000 apabila dibandingkan dengan taraf signifikan yang digunakan pada penelitian ini, maka $0,000<0,05$. Kemudian dapat ditarik kesimpulan bahwa H1 penelitian yaitu nonperforming loan berpengaruh negatif 
signifikan terhadap return on asset selama periode 2015 sampai 2019.

Tabel di atas juga memperlihatkan nilai Sig.yang dimiliki variabel LDR yaitu 0,992 dan jika dibandingkan dengan taraf signifikan penelitian ini, maka $0,992>0,05$. Artinya nilai Sig. yang dimiliki oleh variabel LDR lebih besar dari taraf signifikan penelitian ini. Sehingga dapat disimpulkan bahwa $\mathrm{H} 2$ penelitian yakni loan to deposit ratio berpengaruh negatif terhadap return on asset selama 2015 sampai 2019.

Pengujian statistik di atas juga menyajikan nilai Sig. yang dimiliki oleh variabel BOPO sebesar 0,000 dimana apabila dibandingan dengan taraf signifikan penelitian ini. Maka $0,000<$ 0,05. Yang berarti nilai Sig. BOPO lebih kecil dari taraf signifikan penelitian ini. Sehingga dari hal tersebut dapat disimpulkan bahwa $\mathrm{H} 3$ penelitian yaitu beban operasioanl terhadap pendapatan operasional berpengaruh negatif terhadap return on asset periode 2015 sampai 2019.

\section{KESIMPULAN DAN SARAN}

Setelah melakukan penelitian dan menganalisis hasilnya, penulis dapat memberikan beberapa kesimpulan seperti:

1) Hal ini membuktikan bahwa risiko kredit mampu mempengaruhi bahkan mengurangi profitabilitas perusahaan. Penanganan terhadap kredit bermasalah dianggap perlu, demi menjaga profitabilitas yang stabil karena hal ini mampu mempengaruhi keputusan investasi para stakeholder.

2) Banyaknya dana pihak ketiga yang diterima digunakan untuk memenuhi loan request dan bunga yang diterima dari penyaluran loan request tersebut digunakan untuk membayar kembali penarikan nasabahnya menunjukkan tidak terdapatnya pengaruh yang diberikan pada profitabilitas. Dikarenkan penghasilan bank tidak berasal dari bunga kredit saja, melainkan dihasilkan juga oleh pendapatan lain yang berbasis komisi.

3) Yang membuktikan bahwa risiko operasional sangat berdampak dan mampu mengurangi profitabilitas perusahaan. Beban operasional yang berjumlah besar dari pendapatannya sangat mempengaruhi operasional perusahaan. Stakeholder menganggap perusahaan tersebut tidak efisien dalam menjalankan usahanya, sehingga berpengaruh terhadap keputusan dalam berinvestasi.

\section{DAFTAR PUSTAKA}

Nwude, E., \& Okeke, C. (2018). Impact of Credit Risk Management on the Performance of Selected Nigerian Banks. International Journal of Economics and Financial Issues, 287-297.

Ansori, H. R., \& Safira. (2018). Analisis Pengaruh Manajemen Risiko Terhadap Profitabilitas (Studi Komparatif Pada Bank Umum Konvensional dan Bank Umum Syariah yang Terdaftar di OJK Periode 2012-2015). Jurnal Profita, 1-19.

Attar, D., Islahuddin, \& M. Shabri. (2014). Pengaruh Penerapan Manajemen Risiko Terhadap Kinerja Keuangan Perbankan Yang Terdaftar Di Bursa Efek Indonesia. Jurnal Akuntansi Pascasarjana Universitas Syiah Kuala, 10-20. 
Badawi, A. (2017). Effect of Credit Risk, Liquidity Risk, and Market Risk Banking to Profitability Bank. European Journal of Business and Management, 1-8.

Bilian, F., \& Purwanto. (2017). Analisis Pengaruh CAR, NIM, BOPO, dan LDR Terhadap Profitabilitas Bank Persero. Firm Journal Of Management Studies; VOL 2, NO.1 (2017), 155-168.

Brigham, F., \& Houston, J. (2011). In F. Brigham, \& J. Houston, Manajemen Keuangan. Edisi Delapan. Versi Indonesia. Jakarta: Erlangga.

Dwihandayani, D. (2017). Analisis Kinerja Non Performing Loan (NPL) Perbankan Di Indonesia Dan Faktor-Faktor yang Mempengaruhi NPL. urnal Ekonomi Bisnis, 265-274.

Fahmi, I. (2012). Analisis Kinerja Keuangan. Bandung: Alfabeta.

Fahmi, I. (2016). Manajemen Risiko Teori, Kasus dan Solusi. Bandung: Alfabeta.

(2018). In I. Ghozali, Aplikasi Analisis Multivariate Dengan Program IBM SPSS 25 EDISI 9 (pp. 1490). Semarang: Badan Penerbit Universitas Diponegoro.

Hutagalung, E. N., Djumahir, \& Ratnawati, K. (2013). Analisa Rasio Keuangan terhadap Kinerja Bank Umum di Indonesia. Jurnal Aplikasi Manajemen, 122-130.

İncekara, A., \& Çetinkaya, H. (2019). Credit Risk Management: A Panel Data Analysis on The Islamic Banks in Turkey. Procedia Computer Sience, 947954.
Indonesia, B. (n.d.). Surat Edaran Bank Indonesia Nomor 13/30/DPNP Tanggal 16 Desember 2011 (Lampiran 14).

Ismanto, D. (2020). Pengaruh Penerapan Manajemen Risiko Terhadap Kinerja Keuangan Sektor Perbankan Periode 2013-2017. Jurnal Fokus Volume 10 No. 1, 102-120.

Kansil, D., Murni, S., \& Tulung, J. E. (2017). Pengaruh Risiko Perbankan Terhadap Kinerja Keuangan Tahun 2013-2015 (Bank Pembangunan Daerah SeIndonesia). Jurnal EMBA, 35083517.

Mansyur, N. (2017). Impact Financial Risk on Financial Performance Bank in Indonesia. The International Journal Of Business \& Management, 305310.

Mardiana. (2018). Pengaruh Manajemen Risiko Terhadap Kinerja Keuangan (Study Pada Perbankan Syariah Yang Terdaftar Di Bei). IQTISHODUNA Vol. 14 No. 2 Tahun 2018, 151-166.

Muhamad, N. K. (2015). Pengaruh CAR, NPL, DAN BOPO Terhadap Profitabilitas Dan Return Saham Pada Bank-Bank Yang Terdaftar Di BEI Tahun 2009-2013. Jurnal EMBA, 258-269.

Munawaroh, D., \& Azwari, P. C. (2019). Effect of Risk Based Bank Rating on Financial Performance of Sharia Commercial Banks. Akuntabilitas: Jurnal Ilmu Akuntansi, 201-214.

Pratiwi, D. (2017). Pengaruh Penerapan Manajemen Risiko Terhadap Kinerja Keuangan Industri 
Perbankan. Jurnal Akuntansi Bisnis Vol. 10 No. 1 (2017), 7393.

Santosa. (2019). Pengaruh Manajemen Risiko Terhadap Kinerja Keuangan Pada Bank Pembiayaan Rakyat Syariah Di Yogyakarta Dan Jawa Tengah. Proceedings 6th NCAB (National Conference on Applied Business), 314-319.

Sathyamoorthi C. R, Mapharing, M., Mphoeng , M., \& Dzimiri, M. (2020). Impact of Financial Risk Management Practices on Financial Performance:Evidence from Commercial Banks in Botswana . Applied Finance and Accounting, 25-39.

Sawir, A. (2001). Analisis Kinerja Keuangan dan Perencanaan Keuangan Perusahaan. Jakarta: PT Gramedia Pustaka Utama.

Septyaning, M. Y. (n.d.). Analisa Kinerja Bank Dengan Penerapan Metode Risk-Based Bank Rating.

Setiawan, S., \& Diansyah. (2018). Pengaruh CAR, BOPO, NPL, Inflasi Dan Suku Bunga Terhadap Profitabilitas Pada Bank Umum Konvensional Yang Terdaftar Di Bursa Efek Indonesia. Media Manajemen Jasa, 1-17.

Simatupang, H. (2019). Peranan Perbankan Dalam Meningkatkan Perekonomian Indonesia. Jurnal Riset Akuntansi Multiparadigma (JRAM) Vol.6, No.2, 136-146.

Sudiyanto, B. (2010). Analisis Pengaruh Dana Pihak Ketiga, BOPO, CAR dan LDR Terhadap Kinerja Keuangan Pada Sektor Perbankan Yang Go Public Di Bursa Efek Indonesia (BEI).
Dinamika Keuangan dan Perbankan, 125-137.

Syamsuddin, L. (2007). Manajemen Keuangan Perusahaan. Jakarta: Raja Grafindo Persada.

Tassew, A. W., \& Hailu, A. A. (2019). The Effect Of Risk Management On Financial Performance Of Commercial Banks In Ethiopia. Financial Studies, 25-38. 